\title{
RESEARCH OF THE INFLUENCE OF SOCIO- DEMOGRAPHIC CHARACTERISTICS OF TOURISTS ON THE CHOICE OF A TRAVEL DESTINATION IN THE CONTEXT OF COVID-19 PANDEMIC
}

\author{
Sara Kostic \\ Faculty of Economics in Subotica, University in Novi Sad, Republic of Serbia \\ Bojana Kovačević Berleković \\ Novi Sad School of Business, Republic of Serbia
}

\begin{abstract}
Socio-demographic characteristics are proven vital in terms of different elements associated with choosing a tourist destination. The tourism industry in the time of Covid-19 has experienced numerous challenges. This research aims to examine the listed elements in the context of the socio-demographic characteristics of respondents. The research results will answer the question if respondents who planned to spend summer holidays abroad in 2020, and that destination was replaced with a domestic destination, statistically significantly differ by some socio-demographic characteristics in comparison to those that planned to travel abroad and succeeded. The results show no differences in social-demographic characteristics and show that respondents who replaced tourist destinations abroad with a domestic ones are more eager to do that again in the future. Following obtained results of the research, the authors point to key conclusions and recommendations.
\end{abstract}

Keywords: Covid-19 pandemic, socio-demographic characteristics, tourism industry, travel destination choice

JEL classification: $M 31$

sara97kostic@gmail.com 


\title{
ISTRAŽIVANJE UTICAJA SOCIODEMOGRAFSKIH KARAKTERISTIKA TURISTA NA ODABIR TURISTIČKE DESTINACIJE U USLOVIMA PANDEMIJE COVID-19
}

\begin{abstract}
Sažetak: Sociodemografske karakteristike pokazale su se kao veoma značajne u pogledu različitih elemenata koji se povezuju sa izborom turističke destinacije. Turistička privreda je, u uslovima pandemije izazvane virusom Covid-19, bila izložena brojnim izazovima. Cilj ovog istraživanja podrazumeva sagledavanje pomenutih elemenata $u$ kontekstu sociodemografskih karakteristika ispitanika. Rezultati istraživanja će pružiti odgovor na pitanje da li se ispitanici koji su planirali da u 2020. godini letuju u inostranstvu, a koji su planiranu inostranu turističku destinaciju zamenili domaćom, statistički značajno razlikuju po nekoj od sociodemografskih karakteristika u odnosu na one ispitanike koji su takođe planirali da otputuju u inostranstvo, $i$ u tome $i$ uspeli. Rezultati ukazuju na to da razlike po sociodemografskim karakteristikama između ispitanika nema, ali ukazuju $i$ na to da oni ispitanici, koji su zamenili inostranu turističku destinaciju domaćom, pokazuju veći stepen verovatnoće da će i ubuduće preduzeti istu akciju. U skladu sa dobijenim istraživačkim rezultatima, autori na kraju rada ukazuju na ključne zaključke i preporuke.
\end{abstract}

Ključne reči: pandemija Covid-19, sociodemografske karakteristike, turistička privreda, odabir turističke destinacije

\section{INTRODUCTION}

In conditions of a pandemic caused by the virus Covid-19, the tourism economy was exposed to numerous challenges that needed an adequate reaction. Analysis of the Covid-19 pandemic quickly became a theme in scientific circles, so in existing literature, there are researches focused on other industrial segments, such as the production sector and possibilities for product placement. (Marić \& Đurković-Marić, 2020). On the Republic of Serbia territory, the first cases of Covid-19 virus infection were registered during March of 2020, which influenced the fall of the demand for touristic services in the same month. According to the Statistical Office of the Republic of Serbia, in March of 2020, compared to March of 2019, the number of tourist departures was 56\% lower. The number of overnight stayings was reduced by $45,7 \%$. Then, in December 2020, compared to December 2019, the number of tourist departures showed a reduction of $67,1 \%$, and the number of overnight stays was $59,9 \%$ lower. The greatest decline of the number of tourists in 2020 compared to 2019 was noted 
66 | Research of the influence of socio-demographic characteristics of tourists on the choice of a travel destination in the context of COVID-19 pandemic

in April, as it reached a 97,9\% decline in April of 2019. Within described circumstances, the Tourism Organisation of Serbia decided to implement the digital campaign "Stay home today, so you can travel tomorrow", which was imported from the World Tourism Organisation.

Due to listed circumstances, a great number of the Republic of Serbia citizens have not succeeded in traveling to planned destinations abroad. This paper aims to analyze the socio-demographic factors that influence choosing domestic instead of overseas tourist destinations within the Covid-19 pandemic in the Republic of Serbia. This research aims to identify socio-demographic characteristics that have a statistically significant influence.

The paper itself has four chapters. Firstly, there is a description of motives for research conducting and the importance of researching this particular problem. Then a literature review talks about the significance of socio-demographic characteristics as important elements for choosing a tourist destination. Data used in the research were gathered by the survey method, and questionnaires were distributed using different Internet platforms.

Based on the gathered data, two research segments of respondents were identified. During the process of comparison of these segments, descriptive statistical analysis is implemented. After that, for comparison of respondents by gender and marital status, $\chi 2$ test was used. Furthermore, the t-test of independent means was used to make comparisons of respondents by age, years of education, self-estimated income, number of household members, and the existence of probability to holiday planned abroad change to holiday in Serbia in the future.

The results of research conducted lead to the conclusion that there are no statistically significant differences between segments of respondents in sociodemographic characteristics and the choice of tourist destination in conditions of Covid-19 pandemic. However, the special value of this research is the conclusion that there is a statistically significant difference in the probability of choosing a planned tourist destination abroad in exchange for a destination in the Republic of Serbia.

\section{LITERATURE REVIEW}

In the scientific literature, numerous researches are dealing with the influence of socio-demographic factors within the context of elements important for touristic services choice, indirectly when the choice of tourist destination is in question. In this respect, it is possible to single out: gender (Fodness, 1992; Hudson, 2000; Meng \& Uysal, 2008; Kim, Kim, Park \& Guo, 2008; Tangeland, Aas \& 
Odden, 2013; Đeri, Božić \& Šašlić, 2017; Aziz, Hussin, Nezakati, Yusof \& Hashim, 2018; Karatsoli \& Nathanail, 2020; Remoaldo, Ghanian \& Alves, 2020), age (Luo \& Deng, 2007; Jönsson \& Devonish, 2008; Tangeland, Aas \& Odden, 2013; Schroeder \& Pennington-Gray, 2014; Aziz et al., 2018; Anson, Chow, Cheung, Lee \& Liu 2018), level of education (Kim, Kim, Park \& Guo, 2008; Tangeland, Aas \& Odden, 2013; Anson et al., 2018), family status (Kattiyapornpong, 2009; Chen, 2009; Anson et al., 2018), and amount of income (Kattiyapornpong, 2009; Aziz et al., 2018; Anson et al., 2018; Escobar, López, Pérez-Priego \& García-Moreno, 2020).

Karatsoli \& Nathanail (2020) describe gender as a relevant variable for tourist destination choice. Namely, when it comes to a tourist's gender and the use of social networks in tourist destination planning, authors conclude that female tourists react more intensively to information placed on social networks when choosing a tourist destination than male tourists. Besides, there is also a difference in making decisions about touristic services purchase. Male tourists make decisions easily and intuitively, and female tourists mostly have to take advice from family members and/or friends. (Đeri, Armenski \& Jovanović, 2014).

Fodness (1992) concludes that female tourists more often choose a tourist destination for family trips with kids than for family trips without children (Fodness, 1992). In planning to visit certain tourist destinations, tourists of both genders are prone to be influenced by reviews, ratings, photographs, videos and suggested transport means (Karatsoli \& Nathanail, 2020). Moreover, Remoaldo, Ghanian and Alves (2020) stress that female tourists more intensively show "intention" and "total satisfaction" than male tourists for creative touristic activities. Still, on the other hand, male tourists are more active in activities in nature (Tangeland, Aas \& Odden, 2013). Hudson (2000) points out female tourists are more afraid of possibilities for injuries during visits to tourist destinations, mostly in ski centers, in comparison to male tourists.

Meng and Uysal (2008) have determined differences in the perception of natural factors in tourists of opposite genders in visiting tourist destinations. In this context, when it comes to holidays in nature, female tourists have a more intense desire to spend time with family and friends, coupled with relaxation and rest. Male tourists in their twenties and married show the greatest desire to visit tourist sites again. (Kim, Kim, Park \& Guo, 2008).

However, some literature research does not consider the gender of respondents to be a significant variable for choosing a tourist destination. The above mentioned especially stands out in the influence of tourists' motivation for visiting certain tourist destinations (Jönsson \& Devonish, 2008). Similar 
68 Research of the influence of socio-demographic characteristics of tourists on the choice of a travel destination in the context of COVID-19 pandemic

attitudes are presented by other authors pointing out that gender, as a sociodemographic variable, does not influence the desire for traveling. (Aziz et al., 2018). The group of authors observe the absence of difference in the motivation of tourists of both genders but still conclude that female tourists value motivation factors more than male tourists (Meng \& Uysal, 2008). Besides, when it comes to prices and ways of payment for touristic arrangements, there is no difference in reaction between male and female tourists (Đeri, Božić \& Šašlić, 2017). In addition, Remoaldo, Ghanian and Alves (2020) point out that there is no difference between male and female tourists participating in creative activities during excursions.

The next socio-demographic characteristic that stands out as very significant for decision-making is the age of tourists. Namely, tourists' age influences cultural motivation, especially for tourists of older generations (Jönsson and Devonish, 2008). Also, Jönsson Jonson and Devonish (2008) say that for older tourists, in comparison to younger ones, it is more important to get to know the characteristics of local places and their inhabitants, and younger tourists prefer destinations where they can participate in various sports activities. Besides that, there is a significant difference in the age of tourists and their desire to travel (Aziz et al., 2018). Tourists between 31 and 40 years of age had more opportunities to use social networks for informing in periods of crisis (crisis situations can be grouped within twelve kinds of crises such as terrorism, criminal, natural disasters, diseases (as SARS), food safety, financial, health and cultural barriers) in comparison to those between 18 and 30 years of age (Schroeder \& Pennington-Gray, 2014). The other authors in their research mention the positive correlation between tourists' age and feeling of relaxation, exploration of nature and visiting national parks (Anson et al., 2018). Furthermore, the other group of authors stresses the existence of a significant negative correlation between tourists' age and their participation in adventurous activities (Tangeland, Aas \& Odden, 2013). Luo and Deng (2007) tell that there is a negative correlation between the age of respondents and their desire for new things and permanent work on themselves (new things and permanent work on themselves mean new experiences, excitements, meeting new people, developing new abilities and skills). The conclusion is that younger respondents prefer new things in tourism (Luo \& Deng, 2007).

When it comes to exploring the influence of the education level of tourists as a socio-demographic characteristic, in literature, there are different researchers' attitudes. Kim, Kim, Park \& Guo (2008) conclude that the higher satisfaction level during visiting tourist destinations shows respondents with higher education levels. Moreover, it is evident that more educated respondents show lower levels of satisfaction, so there is a negative correlation between the 
education level and social influence (Anson et al., 2018). Authors have researched respondents' satisfaction by asking questions about public transport availability, tourist destination management, the safety of objects, availability of information about tourist destinations, the attractiveness of touristic destinations, etc. In the same research, social influence is related to the influence of friends and family in making decisions about visiting certain tourist destinations. A group of authors concludes that there is no statistically significant difference between tourists' education level and their desire to perform specific activities, such as fishing on holidays (Tangeland, Aas \& Odden, 2013).

Family status is a socio-demographic characteristic that many authors are focused on in their research. For example, a group of authors concludes that families with small children are often limited in participation in hunting, walking, skiing and some other adventurous activities (Anson et al., 2018). As children grow and become more independent, those limits are reduced. Kattiyapornpong (2009) points out that families more often decide to visit national tourist destinations in comparison to individual tourists. In addition, Chen (2009) has determined that families travel more often to domestic tourist destinations.

In research studies that deal with socio-demographic factors that influence touristic decisions, the variable of interest was also the income level of tourists. Hence, Anson et al. (2018) show that monthly incomes and duration of visiting a certain tourist destination are strongly correlated to social influence that relates to the motivation of respondents to choose a tourist destination under the influence of their family, friends and others whose opinions they value. In addition, it is observed that level of income has an influence on planning tourist trips since the groups with higher incomes are prone to planning short trips within domestic tourist destinations, in comparison to groups of tourists with lower incomes (Kattiyapornpong, 2009). There are conclusions that tourists that visit Córdoba have medium to high purchase power (Escobar et al., 2020). It is possible, in literature, to find studies which results show that amount of income does not influence the greater desire for traveling (Aziz et al., 2018). Still, it is certain that the amount of income strongly influences decision-making about tourist destinations (Đeri, Božić \& Šašlić, 2017).

\section{METHODOLOGY}

Data gathering was performed using a survey method. The questionnaire includes three parts, and it is distributed to respondents using the Internet. The first part of the questionnaire relates to socio-demographic characteristics of respondents: gender, age, years of education, a self-estimated income of 
70 | Research of the influence of socio-demographic characteristics of tourists on the choice of a travel destination in the context of COVID-19 pandemic

household (from 1 to 5 ; 1 - the lowest mark, 5 - the highest mark), family status (married, single), number of members in the household. The second part of the questionnaire includes questions about respondents' plans for the holiday in 2020 and if they have chosen to visit a domestic destination instead of a previously planned holiday abroad. The third part of the questionnaire referred to the probability of exchanging tourist destinations abroad for domestic ones, even after the end of the Covid-19 pandemic (from 1 to 5 ; 1 - it is not probable at all, 5- very probable).

The research was conducted in March of 2021 by distributing the questionnaire (Google Forms) using the Internet. The sample included 330 respondents of both genders. $27 \%$ of respondents were male, and $73 \%$ female gender. The average duration of education was 15.96 years (standard deviation 2.23) which implies that respondents, on average, have high education. When it comes to marital status, $40.3 \%$ of respondents are married, and $59.7 \%$ are single. The average age of respondents is 33.92 (standard deviation 12.32), and the average number of household members is 3 (standard deviation 1.36). The income of their households, respondents estimated at 3.59, on average.

Based on gathered data, two research segments were identified. The first segment were respondents who planned to spend their 2020 holiday abroad. However, due to the emergence of the Covid-19 pandemic, they still decided to visit a domestic destination within the borders of the Republic of Serbia. The other segment were respondents who acted in the opposite way, that is, despite the pandemic, they visited previously planned destinations abroad.

According to the previously stated and defined goal of the research, the authors have defined next null and alternative research hypotheses:

Ho: Tourists from the Republic of Serbia who planned visit to tourist destination abroad in 2020 and have exchanged their destination for a tourist destination in the Republic of Serbia, due to the Covid-19 pandemic, are statistically significantly different in socio-demographic characteristics from tourists that have realized their planned visit to tourist destination abroad.

Ha: Tourists from the Republic of Serbia who planned visit to tourist destination abroad in 2020 and have exchanged their destination for tourist destination in the Republic of Serbia, due to the Covid-19 pandemic, are not different in socio-demographic characteristics from tourists that have realised their planned visit to tourist destination abroad.

In the process of comparison of these segments, the descriptive statistical analysis was used first. After that, for comparison of respondents according to gender and marital status, $\chi^{2}$ test was applied, and in other cases, the t-test of 
independent samples was performed to make the comparison of respondents by age, years of education, self-estimated income, number of household members and the existence of probability for exchanging planned holiday abroad for a holiday in the Republic of Serbia.

\section{THE DISCUSSION OF THE RESEARCH RESULTS}

The research results show that $75.2 \%$ of respondents had plans to go on holiday in 2020. Considering only these respondents, it may be concluded that $62.1 \%$ of them made the exchange of previously planned holiday abroad in 2020, and they decided to visit some domestic tourist destination. On the other hand, according to previous plans, 37.9\% of respondents during 2020 still travelled abroad. The results of the comparison of those two segments are shown in Table 1 and Table 2.

Table 1

The comparison of respondents according to gender and marital status using $\chi^{2}$ test

\begin{tabular}{|c|c|c|c|c|}
\hline & \multicolumn{2}{|c|}{ Gender of respondents } & \multicolumn{2}{c|}{ Marital status of respondents } \\
\cline { 2 - 5 } & Male $(\%)$ & Female $(\%)$ & Married $(\%)$ & Single $(\%)$ \\
\hline Segment 1 & 26.0 & 74.0 & 43.5 & 56.5 \\
\hline Segment 2 & 25.5 & 74.5 & 39.4 & 60.6 \\
\hline & \multicolumn{2}{|c|}{$\chi^{2}(\mathrm{df}=1)=0.006$} & \multicolumn{2}{c|}{$\chi^{2}(\mathrm{df}=1)=0.412$} \\
Test results & \multicolumn{2}{|c|}{$\mathrm{p}=0.938>0,05$} & \multicolumn{2}{c}{} \\
\end{tabular}

Note: Calculation of authors.

The presented results show no statistically significant difference between segments of respondents when it comes to socio-demographic characteristics. However, there is a statistically significant difference in probability that respondents would decide to exchange the planned visit to a tourist destination abroad for a holiday for some domestic tourist destinations even after the end of the Covid-19 pandemic.

Based on that, it may be concluded that the null hypothesis is rejected and the alternative hypothesis is accepted, so authors state that tourists from the Republic of Serbia who planned to visit tourist destinations abroad in 2020 have exchanged for tourist destinations in the Republic of Serbia, due to Covid-19 
72 Research of the influence of socio-demographic characteristics of tourists on the choice of a travel destination in the context of COVID-19 pandemic

pandemic, are not different in socio-demographic characteristics, from tourists that have realized their planned visit to tourist destination abroad.

Table 2

The comparison of respondents according to other variables using $t$-test of independent samples

\begin{tabular}{|c|c|c|c|c|}
\hline \multirow[t]{2}{*}{ Variables } & \multicolumn{2}{|c|}{ Segment 1} & \multicolumn{2}{|c|}{ Segment 2} \\
\hline & $M$ & $S D$ & $M$ & $S D$ \\
\hline \multirow[b]{2}{*}{ Test results } & 33.27 & 11.89 & 34.29 & 11.55 \\
\hline & \multicolumn{4}{|c|}{$\begin{array}{l}t(d f=246)=-0.663 \\
p=0.508>0.05\end{array}$} \\
\hline \multirow[t]{2}{*}{ Years of education } & 16.01 & 2.32 & 16.04 & 2.15 \\
\hline & \multicolumn{4}{|c|}{$\begin{array}{l}t(d f=246)=-0.122 \\
p=0.903>0.05\end{array}$} \\
\hline \multirow[t]{2}{*}{ Number of household members } & 3.36 & 1.25 & 3.36 & 1.54 \\
\hline & \multicolumn{4}{|c|}{$\begin{array}{c}\mathrm{t}(\mathrm{df}=246)=0.011 \\
\mathrm{p}=0.991>0.05\end{array}$} \\
\hline \multirow[t]{2}{*}{ Self estimated income } & 3.68 & 0.9 & 3.63 & 0.87 \\
\hline & \multicolumn{4}{|c|}{$\begin{array}{l}\mathrm{t}(\mathrm{df}=246)=0.464 \\
\mathrm{p}=0.643>0.05\end{array}$} \\
\hline \multirow[t]{2}{*}{ Probability of destination exchange } & 3.24 & 1.41 & 2.85 & 1.52 \\
\hline & \multicolumn{4}{|c|}{$\begin{array}{c}\mathrm{t}(\mathrm{df}=246)=2.045 \\
\mathrm{p}=0.042<0.05\end{array}$} \\
\hline
\end{tabular}

Note. Calculation of authors. ( $\boldsymbol{M}$-Mean; $\boldsymbol{S D}$-Standard Deviation $)$. 
The research results of this study are different from the usually obtained since none of the researched socio-demographic characteristics of respondents have not shown as relevant in intentions to during the last year, make the exchange of a tourist destination abroad for a domestic one. In most of the previous research studies, namely socio-demographic variables show high statistical significance. For example, the gender of respondents is a statistically significant variable in research of Fodness (1992); Hudson (2000); Kim, Kim, Park \& Guo (2008); Meng \& Uysal (2008); Tangeland, Aas \& Odden (2013); Karatsoli \& Nathanail, (2020). Contrary to the above, in literature is possible to find studies which authors were dealing with the same problem and determined that gender of respondents is not a relevant variable (Jönsson \& Devonish, 2008; Meng et al., 2008; Đeri, Božić \& Šašlić, 2017; Aziz et al., 2018; Remoaldo, Ghanian \& Alves, 2020). A similar situation is found when it comes to the age of the respondents. The absence of statistically significant difference between the segments according to age is not in accordance with results of previous researches (Jönsson et al.,2008; Luo et al., 2007; Tangeland et al., 2013; Schroeder et al., 2014; Aziz et al., 2018; Anson et al., 2018).

Besides listed, results of this research show that the family status of respondents is not a significant variable, and that is in harmony with the research of Anson et al. (2018). However, some studies stress the significance of family status as a socio-demographic characteristic of respondents (Kattiyapornpong, 2009; Chen, 2009).

The absence of a statistically significant difference between segments is present in the case of years of education of respondents. Similar results have also been obtained from other researchers as Tangeland, Aas and Odden (2013) and Anson et al. (2018). Still, there are studies in which there is shown a connection between years of respondents' education and their choice of a tourist destination (Kim, Kim, Park \& Guo, 2008).

However, self-estimated income has shown itself as an irrelevant variable in choosing a touristic destination, and it is in accordance with the results of Aziz et al. (2018). On the other side, a higher number of research studies concluded that the amount of income significantly influences the choice of a tourist destination. (Kattiyapornpong, 2009; Anson et al., 2018; Escobar et al., 2020).

\section{CONCLUSION}

The research results lead to the conclusion that there are no significant differences between respondents' segments in socio-demographic characteristics. According to that, none of the socio-demographic variables researched in this work influenced the respondents' decision to change their 
74 Research of the influence of socio-demographic characteristics of tourists on the choice of a travel destination in the context of COVID-19 pandemic

previously planned travel abroad for a holiday in 2020, for visiting some of the domestic tourist destinations. However, the particular value of this research is the conclusion that, between the two researched segments, there is a significant difference when it comes to probability to act the same in the future and change a tourist destination abroad for a domestic one.

On the five-grade Likert scale, the average estimate of the probability that the respondents have exchanged tourist destination abroad for tourist destination in the Republic of Serbia during the previous year is 3.24. This average result shows that respondents have estimated this probability above mark 3, which shows a neutral level on the five-grade Likert scale. Previously presented shows that those who visited tourist destinations in the Republic of Serbia last year (although this answer may not be interpreted as a high level of their consent) still show greater willingness to visit some destinations in the Republic of Serbia in the forthcoming period. Of course, it does not tell about their definitive tourist choice. Still, it may be an important message to creators of economic and tourism development policy. It is important to consider it in planning and to improve tourist offers of the Republic of Serbia. The recommendation is that interest groups in tourism should research tourist demand characteristics of the segment of respondents that show intention and willingness to visit tourist destinations in the Republic of Serbia, more than the other respondents.

The research results also indicate the need to define one or more target market segments to which marketing activities would be directed, but also to define key tourist products and primary destinations in the Republic of Serbia, which are assessed as attractive and competitive by these market segments. Accordingly, it is recommended to take various measures in the form of a larger number of tourist vouchers approved by the competent state authorities to encourage national tourism development, and then conduct attractive marketing campaigns through the most popular social networks aimed at target market segments. One of the significant but insufficiently used ways of promotion in the Republic of Serbia is the presentation of attractive, forgotten landscapes in primetime on television channels and their promotion through film and serial programs. In the following period, promotional campaigns for travel in the Republic of Serbia should be conducted by the Tourist Organisation of Serbia, with the active role of local tourist organizations taking over.

One of the directions of future research dealing with the influence of sociodemographic characteristics on the choice of tourist destination in the conditions of the Covid-19 pandemic should be related to providing a larger number of respondents and expanding the research sample. The research, as mentioned 
earlier, pointed out the importance of the part of the tourist demand that is ready to replace the planned tourist destination abroad with one of the destinations in the Republic of Serbia, but not its characteristics and specifics, and the need for such research arises from the above. Also, to improve and further study the development of this topic, the elements of tourist choice, tourist motives and needs should be elaborated in more detail to obtain specific information on target markets and key tourist products in the Republic of Serbia for which there is the greatest interest.

\section{REFERENCES}

Aziz, Y. A., Hussin, S. R., Nezakati, H., Raja Yvakviusof, R. N., \& Hashim, H. (2018). The effect of socio-demographic variables and travel characteristics on motivation of Muslim family tourists in Malaysia. Journal of Islamic Marketing, 9(2), 222-239.

Chen, J. S., Huang, Y. C., \& Cheng, J. S. (2009). Vacation lifestyle and travel behaviors. Journal of Travel and Tourism Marketing, 26(5-6), 494-506.

Đeri, L., Božić, S., \& Šašlić, S. (2017). Analysis of gender differences in destination decision-making: The case study of Zakynthos Island. Megatrend revija, 14(1), 47-62.

Đeri L., Armenski T. \& Jovanović T., (2014). How income influences the choice of tourism destination. Acta Oeconomica, 64(2), 219-237.

Escobar, A. L., López, R. R., Pérez-Priego, M., \& García, M. de los B. G. M. (2020). Perception, motivation, and satisfaction of female tourists with their visit to the city of Cordoba (Spain). Sustainability, 12(18), 7595.

Fodness, D. (1992). The Impact of Family Life Cycle on the Vacation Decisionmaking Process. Journal of Travel Research, 31(2), 8-13.

Hudson, S. (2000). The segmentation of potential tourists: Constraint differences between men and women. Journal of Travel Research, 38(4), 363-368.

Jönsson, C., \& Devonish, D. (2008). Does nationality, gender, and age affect travel motivation? A case of visitors to the Caribbean Island of Barbados. Journal of Travel and Tourism Marketing, 25(3-4), 398-408.

Karatsoli, M., \& Nathanail, E. (2020). Examining gender differences of social media use for activity planning and travel choices. European Transport Research Review, 12(1), 1-9. 
76 | Research of the influence of socio-demographic characteristics of tourists on the choice of a travel destination in the context of COVID-19 pandemic

Kattiyapornpong, U., \& Miller, K. E. (2009). Socio-demographic constraints to travel behavior. International Journal of Culture, Tourism and Hospitality Research, 3(1), 81-94.

Kim, S. S., Kim, M., Park, J., \& Guo, Y. (2008). Cave tourism: Tourists' characteristics, motivations to visit, and the segmentation of their behavior. Asia Pacific Journal of Tourism Research, 13(3), 299-318.

Luo, Y., \& Deng, J. (2008). The new environmental paradigm and nature-based tourism motivation. Journal of Travel Research, 46(4), 392-402.

Anson, T. H. M., Chow, A. S. Y., Cheung, L. T. O., Lee, K. M. Y., \& Liu, S. (2018). Impacts of tourists' socio-demographic characteristics on the travel motivation and satisfaction: The case of protected areas in South China. Sustainability, 10(10), 3388.

Marić R., \& Đurković Marić, T., (2020). Consequences Of Covid-19 Pandemic On Placement Of Consumer Products On The Global Market And The Market Of The Republic Of Serbia. School of Business, 2/2020, 126-141.

Meng, F., \& Uysal, M. (2008). Effects of gender differences on perceptions of destination attributes, motivations, and travel values: An examination of a nature-based resort destination. Journal of Sustainable Tourism, 16(4), 445-466.

Remoaldo, P., Ghanian, M., \& Alves, J. (2020). Exploring the experience of creative tourism in the northern region of Portugal-a gender perspective. Sustainability, 12(24), 1-17.

Republički zavod za statistiku. https://www.stat.gov.rs/

Schroeder, A., \& Pennington-Gray, L. (2015). The Role of Social Media in International Tourist's Decision Making. Journal of Travel Research, 54(5), 584-595.

Tangeland, T., Aas, Ø., \& Odden, A. (2013). The Socio-Demographic Influence on Participation in Outdoor Recreation Activities - Implications for the Norwegian Domestic Market for Nature-Based Tourism. Scandinavian Journal of Hospitality and Tourism, 13(3), 190-207.

Delivered: 18.05.2021

Accepted: 29.11.2021. 